\title{
Givetian-Frasnian phytogeography of Euramerica and western Gondwana based on miospore distribution
}

\author{
MAURICE STREEL ${ }^{1}$, MURIEL FAIRON-DEMARET ${ }^{1}$ \& STANISLAS LOBOZIAK ${ }^{2}$ \\ ${ }^{1}$ Paléontologie, Université, 7 place du vingt-aon̂t, B-4000 Liege, Belgium \\ ${ }^{2}$ Paléobotanique, Université des Sciences et Techniques de Lille, URA 1365, F-59655 Villeneuve \\ d'Ascq, France
}

\begin{abstract}
The Givetian and Frasnian miospore distributions in western Gondwana and southern Euramerica show a rather uniform vegetation prevailing from palaeo-polar to palaeo-tropical regions. Similar climatic conditions are certainly required to explain this but it is concluded from a discussion on the dispersal of homosporous vegetation that no wide reques these regions at the time. Frasnian northern Euramerica vegetation seems different and might correspond to an equatorial belt. Heckel \& Witzke's palaeogeographical reconstruction fits much better with the miospore distribution than other maps.
\end{abstract}

A recent comparison (Loboziak et al. 1989) between MiddleUpper Devonian miospore assemblages from Libya and Brazil led to the following palaeoclimatological conclusions: a rather uniform vegetation and therefore uniform climate prevailed at the time from palaeo-subtropical to palaeo-polar regions in western Gondwana: within the area studied, the climate became progressively more uniform from the Givetian to the Frasnian.

These conclusions were reached after studying borehole sequences originating from nearshore marine palaeoenvironments, it is important to note that both sequences were studied by the same palynologists, thus eliminating investigator bias. Loboziak et al. (1989) observed that characteristic miospores entered the geological record in the same order of succession in both sequences (Fig. 1) and that the small quantitative differences between these sequences were more obvious in Givetian than in Frasnian assemblages (Fig. 2). These comparisons can now be extended to other regions.

\section{Comparison between western Gondwana and southern Euramerica}

Non-palynological dating methods have not been used, but the first occurrences of each characteristic miospore of the Libyan and Brazilian assemblages are the same as those of the western European succession (southern Euramerica in Devonian time), where they form the basis for a miospore zonation which has been related to well documented megafloras and marine faunas (Streel et al. 1987). We have applied the same quantitative analysis, as that performed on the Libyan and Brazilian material, to some previously studied samples from the Boulonnais area (Loboziak \& Streel 1981) and some samples currently being studied from the Eifel area (Fig. 2).

Note that the percentages computed for each sample are based on the number of specimens of each species, and therefore give information on the relative abundance of different components of the vegetation. Ignoring the morphologically simple miospores, most of the 'elaborate miospores' (Fig. 2) from the Givetian and Frasnian of western Europe are of the same species as in Brazil and Libya. This allows the same miospore zonation to be applied across all these regions.

The conclusion of Loboziak et al. (1989) concerning the uniform distribution of vegetation in western Gondwana must now be extended to take account of the information from southern Euramerica: if we accept a palaeo-southern tropical position for this region, as suggested by most of the available palaeogeographical reconstructions, we have to assume that a rather uniform vegetation, and therefore a rather uniform climate, prevailed during Givetian to Frasnian time from palaeo-tropical to palaeo-polar regions.
The similarity of Givetian and Frasnian floras across western Gondwana and southern Euramerica, as suggested by the quantitative analyses of miospores, raises the question of the existence of 'A newly opened ocean ... forming between the Gondwana craton and Laurentia (with Avalonian/Armorican accreted terranes left behind, adjacent to Laurentia) during the Middle and Late Devonian' (Van der Voo 1988, p. 322). Is an ocean more than $2500 \mathrm{~km}$ wide (as shown by Van der Voo, 1988, fig. 5) compatible with the exchange of plant dispersal (propagules) devices and thereby the migration of vegetation?

\section{Land plant miospores as evidence in palaeogeographical reconstructions.}

Land plants 'break up as fossils into leaves and stems (...) and a multitude of spores, pollen, and seeds which all act as small dispersants moving downstream with clastic sedimentation into all resulting sediments wherever they are deposited' (Hughes 1988). Small spores and pollen (miospores) are normally preserved even in fine-grained clastic marine sediments because they are protected by chemically very resistant envelopes.

Some factors affecting spore numbers and composition in sediments. Miospores are produced in enormous amounts by land plants and their usual method of dispersal is by wind. However, Raynor ef al. (1976) state that most (modern fern) spores released will settle to the ground or to other vegetation within relatively short distances, (only) a few may be carried long distances, particularly during periods of strong winds and good atmospheric mixing'. Even very light grass pollen grains are almost all deposited by the wind at a very short distance from the vegetation-source (Moseholm et al. 1987).

After transportation to the sedimentary basins through flooding and fluvial systems, most of the miospores will be deposited nearshore so that only a small proportion of the miospores produced will be carried off-shore by the water-currents (Muller 1959).

Near-shore deposits will still contain high concentrations of miospores (several thousands to several tens of thousands in each gram of a suitable sediment). Off-shore sediments contain a much lower concentration and Traverse \& Ginsburg (1966) have shown that the resulting assemblages are species poor and contain miospores with a restricted range of diameters because of sorting during transport. In the present paper, we have examined only rich assemblages from near-shore marine sediments. We believe that these spores were derived from land plants that grew in the near hinterland, that is in area of a few tens of square kilometres, and that they were transported from this area through the fluvial system. This relatively large catchment area would have contained a variety of different land plant communities and 


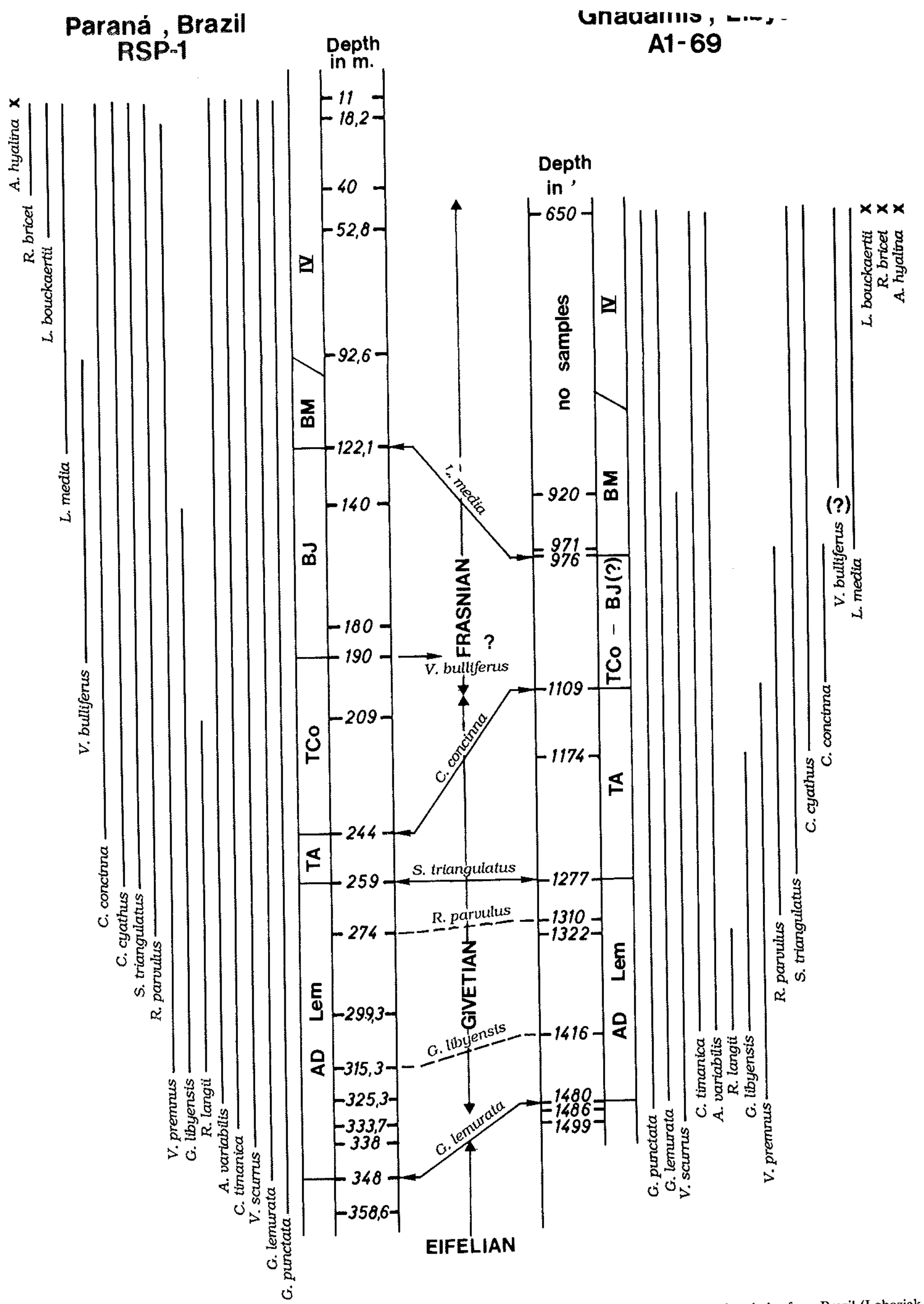

the of thain characteristic Givetian-Frasnian miospores in two boreholes from Brazil (Loboziak et al. 1988) and Libya (Loboziak \& Streel 1989). 

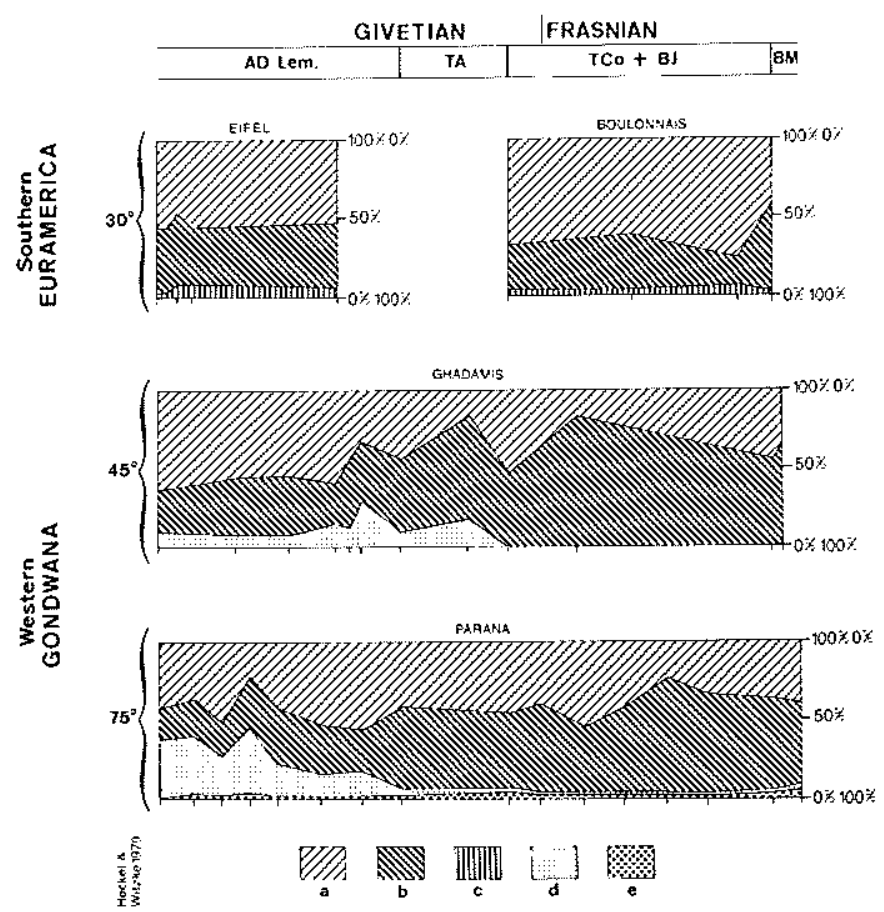

Fig. 2. Quantitative distribution of various miospore classes in different regions of western Gondwana and southern Euramerica. a, morphologically simple (smooth or finely ornamented, one-layered) miospores. $b-c$, morphologically elaborate miospores; $b$, occurring in all regions; $c$, never found in Gondwana; $d$, only found in Gondwana; e, only found in Parana (Brazil). Stratigraphic scale as on Fig. 1. Note that percentages are of specimens, not of species.

thus, unlike other groups of (hyp)-autochthonous organisms, the resulting spore assemblages are less likely to reflect very small scale environmental variation. Some of these miospores may also have been derived from more distant localities through air or water currents but research on modern sediments demonstrates that they are always greatly outnumbered by the local production.

Migration of homosporous land plants by long distance wind dispersal of spores. In theory, a few spores carried casually over long distances are all that is necessary to allow land plants to migrate to a suitable environment. This applies only to homosporous plants, the isolated spores of which have the potential of producing new sporophytes. Heterosporous and seed plants, arising in Middle and Late Devonian times, evolved a restricted number of large propagules (megaspores and seeds) which made the possibility of long distance dispersal improbable.

Also, the megaspores of heterosporous plants are usually shed before fertilization, so even if carried a long distance, they would have to wait for a microspore of the same species to arrive before a new sporophyte could be produced, another unprobable event. A good example of the limitations this imposes on dispersal can be seen in the geographic distribution of the modern heterosporous Selaginella which has been shown by Tryon (1971) to rely entirely on a step by step migration processes resulting in small scale extensions of its geographic range.

References to present-day dispersal processes of homosporous plants are rather scarce and we can discard those related to bryophytes because of the rather small size (usually less than $25 \mu \mathrm{m}$ ) of their spores in comparison to those of most of the supposedly homosporous Middle and Late Devonian plants and modern ferns discussed here (usually 50 to $150 \mu \mathrm{m}$ ).

Nearly all modern ferns are homosporous, with spores that can readily be dispersed in the air over long distances, and a review of various aspects of spore dispersal indicates that these ferns have a great capacity for dispersal by wind (Tryon 1970). This contradicts the view of Copeland (1940) who wrote 'Ten miles of open water is no barrier to their spread, once they are picked up by the wind. A thousand miles, though, seems to be, in general, an impassable barrier'. In the context of this paper, however, we are not so much concerned with chance dispersal over long distances but rather with the probability, given enough time, of the spread of an entire homosporous plant vegetation containing similar components. Studies on isolated islands (Tryon 1970), endemic areas, and geographic speciation in modern tropical American ferns (Tryon 1972) demonstrate that long-distance migration, involving the transport of fern spores over distances of more than $1600 \mathrm{~km}$ to regions where the environment is equivalent to that of the source area, normally induces genetic isolation in the new colony due to a lack of re-immigration. Geographic isolation may be even more effective if the new environment is not equivalent to that of the source area. Tryon (1970) presents evidence that distances greater than $800 \mathrm{~km}$ are sufficient for isolation of an insular fern flora because of the small size of the newly colonized territory. The chances of re-immigration are of course greater with time but when the isolation distance is large, chance needs more time, and the speciation might be quicker than the re-immigration process. It is instructive to compare the present flora of the 10 million year old island for St Helena with those of the geologically younger islands of Ascension and the Tristan da Cunha group. All these islands are at least $2000 \mathrm{~km}$ from the nearest continents. Ascension and the Tristan da Cunha group have a much lower percentage of endemic species $(24 \%$ and $40 \%$ respectively) than has St Helena (52\%) (Muir \& Baker 1968).

Ten million years is about the same timespan covered by the sampling in the three areas studied in the Givetian and Frasnian. During this timespan, about ten bio-events (the first occurrence of some of the listed species in Fig. 1) arose in the same order of succession in all these areas, indicating similar vegetation patterns. Similar climatic conditions are certainly required to explain this but a wide ocean separating these regions would have prevented it.

\section{Plant macrofossil evidence}

The similarity of Givetian and Frasnian floras, as interpreted through the microfossil evidence, across western Gondwana and southern Euramerica appears to contradict the analysis of Devonian floras made by Edwards (1973) which was based on macrofossils; she concluded (page 109) that a distinction between present-day Southern and Northern Hemisphere floras is present in the Middle Devonian. It should be noted however that this conclusion is based on a few inadequately dated South African and Argentinian fossil floras. In any case, being isolated discoveries, they might well correspond to the few percent of miospores restricted to 'the highest palaeolatitudes' (those restricted to the Parana basin, on Fig. 2). On another hand, Edwards \& Benedetto (1985, p. 616) provided 'evidence for a uniform vegetation between a part of north Gondwana (Venezuela) and the Old Red Continent in mid- to late-Devonian times, but (their data) in isolation do not provide compelling evidence for global uniformity during that period. The similarities may simply reflect the palaeogeographic proximity of the localities or their occurrence in encompassing more than one palaeocontinent'. There is no detailed analysis using multivariate statistical tool available for the Middle and Upper Devonian which might be compared to the Lower Devonian analysis proposed by Raymond et al. (1985).

A reappraisal of the published Givetian and Frasnian plant megafossils made by one of us (M. F-D) does not show any clear subdivision of floras across the regions discussed here. It does not demonstrate any continuity either as information has only been obtained from isolated localities where cosmopolitan taxa, if present are often less abundant than 'endemic' species. We 

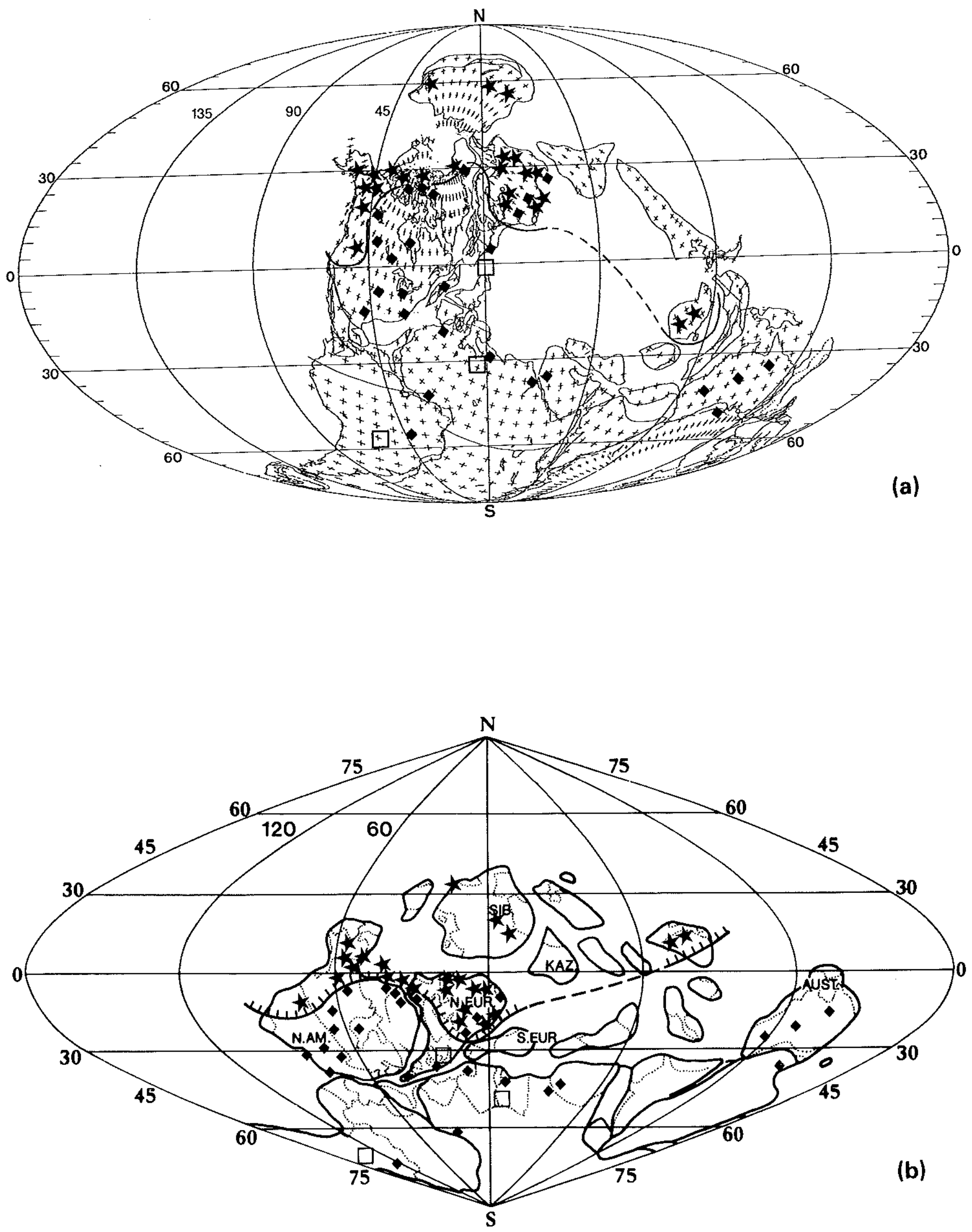

Fig. 3. Palaeophytogeographic reconstructions based on maps by (a) Scotese (1986) and (b) Heckel \& Witzke (1979). Black stars, Archaeoperisaccus distribution after McGregor (1979) and Streel (1986). Black diamonds, Geminospora lemurata distribution after McGregor (1979) and Streel (1986). White square, regions where quantitative data (see Fig. 2) have been evaluated by the authors. 
believe that these megafloral data are too sporadic to be compared with the miospore data. As Hughes (1988, p. 547) remarked: 'In practice, megafossil paleobotany can be regarded as a spatter of very small beautifully formed islands set in an almost unlimited ocean of palynomorphs which inevitably represent the vast majority of fossil plant information that is available'.

\section{Comparison between southern and northern Euramerica}

We were not able to study a sequence of samples from the Givetian and Frasnian of northern Euramerica. Therefore, comparisons with the above data cannot have the same security, as we have had to rely on descriptions and photographs of miospores made by other authors. Moreover, part of northern Euramerica was studied by Russian palynologists at a time when they were often using their own nomenclature and poor illustrations. Richardson \& McGregor (1986, fig. 6) have checked the first occurrence of ten zonally significant miospores in a selection of Givetian and Frasnian spore-bearing strata controlled by conodonts from the western (Canada) and the eastern (USSR) parts of northern Euramerica and from southern (Boulonnais, France) Euramerica. Only four species show north-south correlations. Amongst these four species, Geminospora lemurata and Samarisporites triangulatus are now considered by us to enter the geological record respectively in the latest Eifelian and the middle Givetian of the Ardenne-Rhenish basins. Despite these difficulties, some observations have been made which indicate that at least the Frasnian miospore assemblages are somewhat different from those described in southern Euramerica and western Gondwana. Loboziak \& Streel (1981) for instance found it difficult to correlate conodont dated Frasnian miospore zonations from the USSR and northern France (Boulonnais area). McGregor (1981) remarks that many of the species of the Givetian and the Frasnian of the USSR that are regarded as stratigraphically important by Soviet workers have not been recognized in other regions. He notes that a section on Melville Island in the Canadian arctic provides a palynological bridge between the European USSR and the Boulonnais, as it contains species so far found only in one or the other of these regions. The still unpublished thesis of Braman (1981) contains the most detailed data on the miospores distribution in the middle (?) and late Frasnian (Polygnathus asymmetricus to Palmatolepis gigas conodont zones of the Imperial Fomation, District of Mackenzie and Yukon) for the western part of northern Euramerica. One of us (M. S.) has checked that out of the 95 species recorded, 26 were species of 'elaborate' morphology not present in southern Euramerica and 20 were of undifferentiated simple morphology. Unfortunately, counts made on numbers of specimens of these species are poorly known except that one species (Hymenozonotriletes deliquescens) varies from 19.3 to $26.3 \%$ of the total assemblage. $H$. deliquescens and several species of Archaeoperisaccus are good characteristic species for this timespan in the northern Euramerica (See also McGregor, 1981, figs 3 and 8).

McGregor (1979) and Streel $(1980,1986)$ have plotted, on different palaeogeographical maps, the distribution of Archaeoperisaccus versus other Frasnian miospore assemblages containing Geminospora lemurata. These data are reproduced here (Fig. 3) on two different maps, one proposed for the Givetian by Scotese (1986), the other for the Middle Devonian by Heckel \& Witzke (1979). It should be noted that the last reconstruction is based on the supposition that the palaeomagnetic poles of the earth at that time did not coincide with the rotational poles.

Heckel \& Witzke's reconstruction allows the location of the Archaeoperisaccus flora of northern Euramerica (and South China) in an equatorial belt (between $35^{\circ} \mathrm{N}$ and $20^{\circ} \mathrm{S}$ ) and indicates that the rest of the floras in the southern hemisphere were situated between $10^{\circ}$ and $75^{\circ}$ palaeolatitudes. Following the reconstruction by Scotese, the Archaeoperisaccus flora of northern Euramerica (and South China) would have been randomly distributed between the $60^{\circ}$ northern palaeolatitude and the $30^{\circ}$. southern palaeolatitude. This asymmetrical floral distribution would imply a strongly asymmetrical distribution of climatic belts. Moreover, the western European flora studied in the early part of this paper would occupy an equatorial position with the same characteristics as in palaeo-subtropical and palaeo-polar regions. It would be hard to understand why tropical floras north of the palaeo-equator have no counterpart in the south, especially since no major physical barriers (mountain ranges or wide oceans) can be distinguished between the two realms. Thus, we believe that Heckel \& Witzke's reconstruction fits much better with the miospore distribution than other maps.

\section{Conclusion}

Givetian-Frasnian miospore distributions in western Gondwana and Euramerica suggest a greater contrast in the vegetation between supposedly palaeo-equatorial and palaeo-tropical regions than between palaeo-tropical and palaeo-polar regions. They also favors palaeogeographic models that show a close proximity between Gondwana and Euramerica in the southern hemisphere during this time.

M. J. M. Bless and P. Kenrick are thanked for stimulating suggestions and corrections of language which contributed much to improve the manuscript.

\section{References}

Braman, D. R. 1981. Upper Devonian-Lower Carboniferous miospore biostratigraphy of the Imperial Formation, District of Mackenzie and Yukon. Thesis, Department of geology and geophysics, Calgary, Alberta.

Copeland, E. B. 1940. Antarctica as the source of existing ferns. Proceedings of the Sixth Pacific Sciences Congress, 4, 625-627.

Edwards, D. 1973. Devonian floras. In: Hallam, A. (ed.) Atlas of palaeobiogeography Elsevier, 105-115.

_ \& BenedeTto, J. L. 1985. Two new species of herbaceous ly'copods from the Devonian of Venezucla with comments on their taphonomy. Palaeontology, 28, 3, 599-618.

HeCKel, P. H. \& WITZKE, B. J. 1979. Devonian world palaeogeography determined from distribution of carbonates and related lithic palaeoclimatic indicators. $I n$ : House, M. R., Sckutton, C. T. Bassett, M. G. (eds) The Devonian System Palaeontological Association Special paper, 23, 99-123.

Hughes, N. F. 1988. Plant fossils in Earth Sciences. Geological Magazine, $125,547-549$.

Lobozlak, S. \& StreEL, M. 1981. Miospores in Middle-Upper Frasnian to Famennian sediments partly dated by conodonts (Boulonnais, France). Review of Palaeobotany and Palynology, 34, 49-66.

_._ \& 1989. Middle-Upper Devonian miospores from the Ghadamis Basin (Tunisia-Libya); systematics and stratigraphy. Review of Palaeobotany and Palynology, 58, 173-196.

__ - \& Burjack, M. I. A. 1988. Quelques données nouvelles sur les miospores dévoniennes du Bassin de Paraná (Brésil). Sciences géologiques, 40, 381-391.

,$--\& — 1989$. Déductions paléoclimatiques d'une comparaison entre des assemblages de miospores du Dévonien moyen et supérieur de Libye et du Brésil. Geobios, 22, 247-251.

MCGregor, D. C. 1979. Spores in Devonian stratigraphical correlation. In: House, M. R., Scrutron, C. T., Bassetr, M. G. (eds) The Devonian System Palaeontological Association. Special paper, 23, 163-184.

- 1981. Spores and the Middle-Upper Devonian boundary. Review of Palaeobotany and Palynology, 34, 25-47.

Moseholm, L., Weeke, E. \& Petersen, B. 1987. Forecast of pollen concentrations of Poaceae (Grasses) in the air by time series analysis. Pollen et Spores, 29, 305-322.

Muir, M. D. \& Baker, I. 1968. The early Pliocene flora of St. Helena. Palaeogeography, palaeoclimatology and palaeoecology, 5, 251-268.

Muller, J. 1959. Palynology of recent Orinoco delta and shelf sediments. 
Micropuleontology, 5, 1, 1-32.

Raymond, A., PARKer, W. C. \& Barrett, S. F. 1985. Early Devonian phytogeography. In: Tifrey, B. H. (ed.) Geological factors and the evolution of plants. Yale university press, 129-167.

Raynor, G. S., Ogden, E. C. \& Hayes, J. V. 1976. Dispersion of fem spores into and within a forest. Rhodora, 78, 473-487.

Richardson, J. B. \& McGregor, D. C. 1986. Silurian and Devonian spore zones of the Old Red Sandstone Continent and adjacent regions. Geological Survey of Canada Bulletin, 364.

Scorese, C. R. 1986. Phanerozoic reconstructions: a new look at the assembly of Asia. University of Texas Institute for Geophysics Technical Report, 66.

STREEL, M. 1980. Evidences palynologiques sur les relations entre le climat et la distribution géographique des flores dévoniennes et dinantiennes. Mémoires du Muséum national d'histoire nalurelle-série $B, 27,261-267$.

1986. Miospore contribution to the Upper Famennian-Strunian event stratigraphy. Annales de la Société géologique de Belgique, 109,
$75-92$.

—, Higgs, K., Loboziak, S., Riegel, W. \& Stremans, P. 1987. Spore stratigraphy and correlation with faunas and tloras in the type marine Devonian of the Ardenne-Rhenish regions. Review of Palaeobotany and Palynology, 50, 211-229.

Traverse, A. \& Ginsburg, R. N. 1966. Palynology of the surface sediments of Great Bahama Bank, as related to water movement and sedimentation. Marine Geology, 4, 417-459.

TrYoN, R. 1970. Development and evolution of fern floras of oceanic islands. Biotropica, 2, 76-84.

- 1971. The process of evolutionary migration in species of Selaginella. Brittonia, 23, 89-100.

1972. Endemic areas and geographic speciation in tropical American ferns. Biotropica, 4, 121-131.

VAN DER Voo, R. 1988. Palcozoic paleogeography of North America, Gondwana, and intervening displaced terranes: comparisons of paleo-magnetism with paleoclimatology and biogeographical patterns. Geological Society of America Bulletin, 100, 311-324. 